\title{
What Preschool Age Child's Perceptions About Division in Fair Sharing
}

\author{
Nety Wahyu Saputri ${ }^{1}$, Theresia Ingga Sari ${ }^{1}$, Sahala Martua Ambarita ${ }^{1}$, Rafika Riana \\ Chaniago $^{1}$, Yatini $^{1}$, Dwi Oktariani ${ }^{1}$, Darmawijoyo ${ }^{1 *}$, Somakim ${ }^{1}$ \\ ${ }^{l}$ Mathematics Education Department, Sriwijaya University, Palembang, South Sumatra, Indonesia \\ *Corresponding author. Email: darmawijoyo@unsri.ac.id
}

\begin{abstract}
This study aims to describe the early mathematic skills of preschoolers in the understanding division through the idea of "fairness". The idea of fairness was familiar to children before the division was first encountered formally. The subjects in this study were three children aged 3-5 years. Based on the research results, it is found that children aged 3-5 years already have an initial understanding of the division. This understanding is identified through what is known as 'fair sharing.' Their perception of division can be seen from the subjects' responses and expressions in "fairness" and "equal sharing" activities.
\end{abstract}

Keywords: Fair Sharing, Division, Preschool Age Child's.

\section{INTRODUCTION}

Preschoolers (ages 3 - 5 years) have a sensitivity to mathematics. Children's development in mathematics can be motivated from outside of the educational environment, such as in their home environment when interacting with their family members and the surrounding environment. Children's mathematic skills develop much earlier in the real-world context than in the classroom [1]. Children's activities and interactions with others can offer many opportunities to learn early mathematical concepts and basic principles early. However, the ability to distinguish what children learn from the mathematical learning environment offered to them set high demand on the interpretation process [2].

The mathematics knowledge that the child has is still non-formal. Children at preschool age may already be able to sort numbers 1-10 well. Because the child is often heard numbers one, two, three, and so on, but the advanced knowledge that the child has is not a symbol of the number, but the meaning of the symbol through the objects around it, such as one candy, two candies, three candies, and so on. According to Jean Piaget's theory of cognitive development, children at the age of $3-5$ are at the preoperative stage, where the child at this stage represents mathematical symbols in real objects[3], the child begins to be able to count using concrete objects and group objects based on one particular trait [4].

Children have also recognized the mathematical idea of division at preschool age. The idea can be seen through the concept of "fairness". The idea of fairness is usually familiar to children before the division was first encountered in a formal sense [5]. Children develop basic ideas of division through interaction with others in daily life, starting from preschool [6]. The idea of fairness can arise because children aged 3-5 years naturally have envy feelings if they acquire something different from others that are considered better than they have. Children ages $3-5$ years tend to compare themselves to others. By the time they realize that others have more than them, they will show feelings of envy and jealousy $[7,8]$. In some cases, children aged $3-5$ years experienced unfair distribution will express their disagreements explicitly; or simply perform non-verbal (implicit) responses that can be observed through the child's gestures and expressions [9].

There have been many studies discussing the ability of preschool-aged children in mathematics. Most studies focus on children's early numerical abilities, such as numeral ability and numerical comparing abilities [10-14]. The studies also provide evidence of early mathematic skills for preschoolers as early as possible for further 
mathematical development. Thus, researchers are interested in showing that preschoolers ages $3-5$ years old also have early mathematical skills called division through "fairness" in 'fair sharing'. The real context or object used is food sharing. The selection of the right context also affects the response that the child will show. The context selected in this dividing activity and being a context familiar to the child [15], also avoided heterogeneous objects that made the child consider anything other than quantity [16]. By analyzing the development of early mathematic skills, it is expected to contribute to further mathematics learning to maximize preschoolers' initial abilities.

\section{METHOD}

This research uses a qualitative descriptive method to decrypt the early mathematical understanding of preschoolers in understanding the concept of division through the idea of "fairness". The subjects in this study were three children aged 3-5 years. The first subject (X) is four years four months old, the second subject $(\mathrm{Y})$ is four years five months, and the third subject $(Z)$ is four years nine months old.

The data collection techniques in this study are observation and interview. Observations and interviews are conducted to see the child's response and perception of the idea of "fairness." Observations were also made in selecting subjects and selecting food to be shared with the subject concerning the health of the subject. Observations are made before and during the study and also observations of videos taken during the activity. Observations during the study were focused on each child's response during the activity: verbal responses, gestures, and facial expressions of the subjects, in which each subject would be given the same amount of food. At the same time, interviews are used to determine the extent of the subject's understanding of the initial mathematic and how the subject responds in the foodsharing activity to be verbally conveyed by the subject. The observation and interview data were then analyzed to see the early mathematic understanding of preschoolers in understanding the concept of division through the idea of "fairness" with the context of food sharing.

\section{RESULT AND DISCUSSION}

This research consists of two stages: the preparation stage and the implementation stage.

\subsection{Preparatory Stage}

At the preparatory stage, the steps taken are as follows:
3.1.1. Determine the subject, question the subject's availability, and ask the permission of its parents to participate in the activity

\subsubsection{Determine what snacks to give to the subject}

In determining snacks, the researchers also asked the subjects' mothers to avoid giving the subjects snacks that the subject could not consume, and the researchers also asked about the snacks the subjects liked the most. Based on these discussions, researchers decided to provide four types of snacks: sweets, chocolate, milk packs, and wafers. Each type of food is given at each session, and each of them has the same shape, size, color, and taste. The researchers decided to give different snacks because they worried that if the subjects were given the same food repetitively, they might get angry or take the activity not seriously so that the subject's natural response would be difficult to obtain.

\subsubsection{Determine the location of the activity}

Under the agreement with the subject's parents, the observation takes place in Z's house, where the three subjects will be gathered in the same place.

\subsubsection{Conditions the subject to make the subject comfortable with the situation and learning environment}

Researchers condition subjects by inviting subjects to play with toys to make the subjects more comfortable and familiar, both between subjects and with the researcher. While the subjects play, occasionally, the researcher directs the camera towards the subject so that the subject is more accustomed and not awkward or embarrassed when they are confronted with the camera during the execution. All of these conditions aim to produce a natural response from the subjects.

\subsection{The Implementation Phase}

The implementation stage consists of 4 segments. Subjects were given six foods with the same type, taste, and color in each segment; then, each subject will be given food with the amount of difference.

\section{Segment 1:}

In segment 1 , the provided snack are candies. $\mathrm{X}$ is given one candy, $\mathrm{Y}$ given three candies, and $\mathrm{Z}$ gave two candies.

Subject Y spontaneously gave one candy to $\mathrm{Z}$ (see Figure 1), since subject $Y$ felt that the researcher gave her many candies, but then researchers returned the candy to the Y. It showed that preschool children had had a concern for justice, so spontaneously allocated objects that he acquired evenly if possible [17]. At the same time, $\mathrm{X}$ glanced in the direction of the candy to her friends and said, "how come the other got more than 
mine?" (Figure 2). In contrast, Y's expression was very happy and showed it $\mathrm{Z}$ that he could get more (Figure 3 ). When they were asked "whether the distribution of candies have been right or wrong," $\mathrm{Y}$ and $\mathrm{Z}$ answered right, while the $\mathrm{X}$ only nodded with an expression of disappointment and then looked down. Subject $\mathrm{Y}$ tries to convince subject $\mathrm{X}$ that the division was correct, then subject $\mathrm{Z}$ also looked disappointed and always glancing in the candies' direction belong to subject Y (Figure 4).

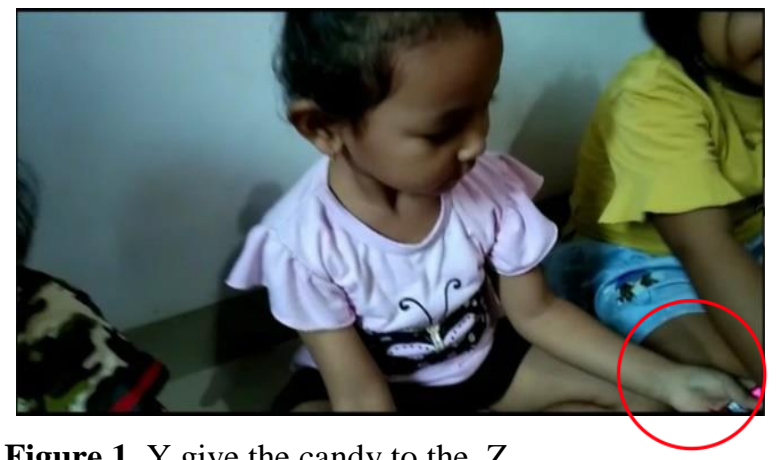

Figure 1. $\mathrm{Y}$ give the candy to the $\mathrm{Z}$

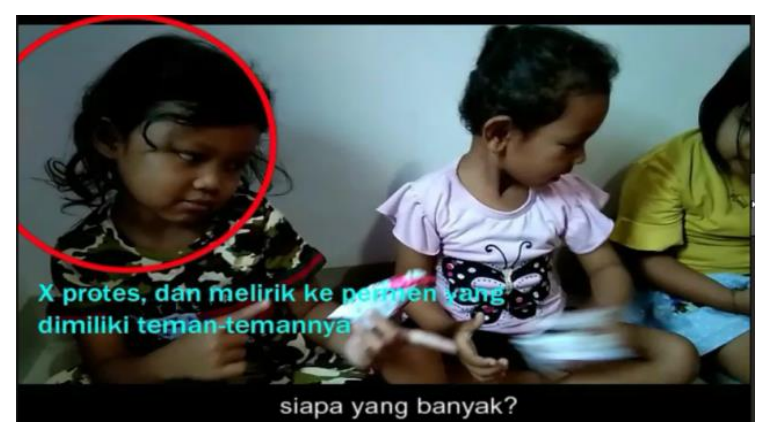

Figure 2. The expression $X$ which when she gets the least candies of all

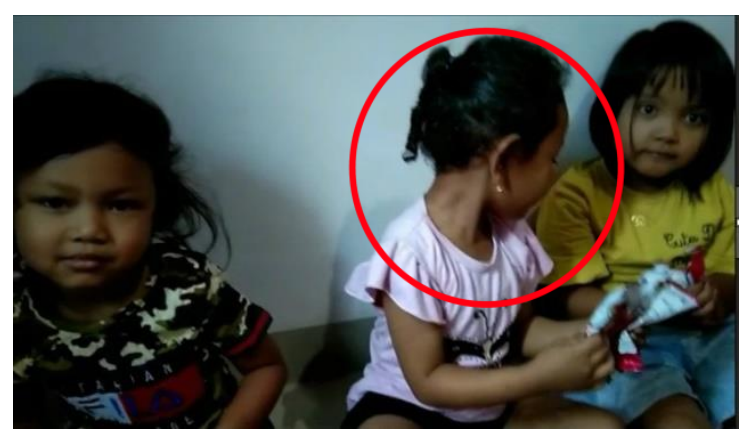

Figure 3. Y looks happy and shows the number of candy to the $\mathrm{Z}$

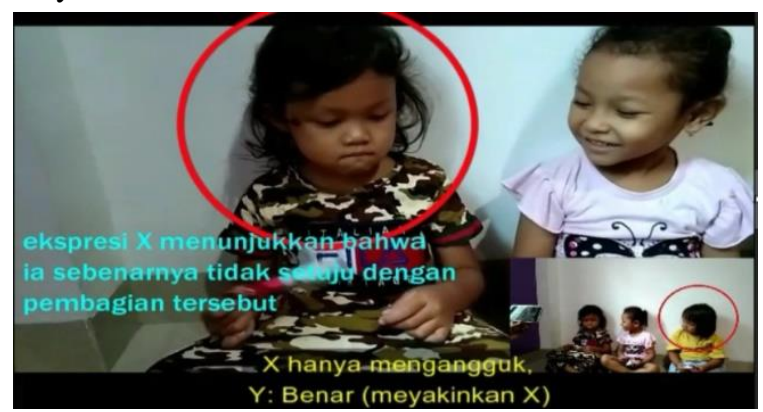

Figure 4. The expression of subject $X$ looked disappointed

\section{Segment 2:}

In segment 2, the provided snack is milk pack. $X$ is given two packs; $\mathrm{Y}$ is given one pack while $\mathrm{Z}$ is given three packs.

$\mathrm{Z}$ looks very happy with the distribution. Meanwhile, $Y$ was seen glancing at the milk packs of his two friends (Figure 5). When asked if the division was correct, $\mathrm{Y}$ just nodded and showed a disappointed expression. After Z replied, "yes," Y also said, "yes." Here $Y$ is seen only imitating Z's answer (Figure 6).

$\mathrm{X}$, who got two packs of milk, is also seen glancing at Z's drink, and when asked if the distribution was correct, $\mathrm{X}$ answered hesitantly and slowly, then $\mathrm{Z}$ replied loudly again, "correct," then $\mathrm{X}$ repeated the word 'true' over and over again times with the less agreeable expression (Figure 7). In the end, $X$ got irritated because he felt $Z$ always got more food than $X$.

In this segment, it is also seen that each subject can count how much food they have.

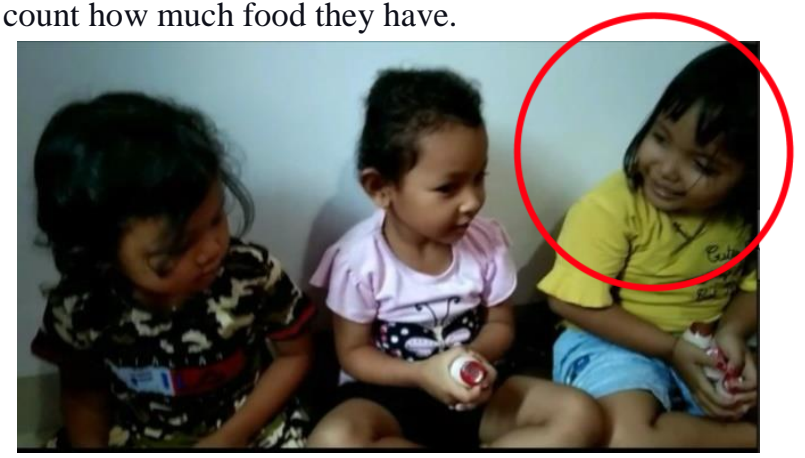

Figure 5. Z looked very happy with the distribution

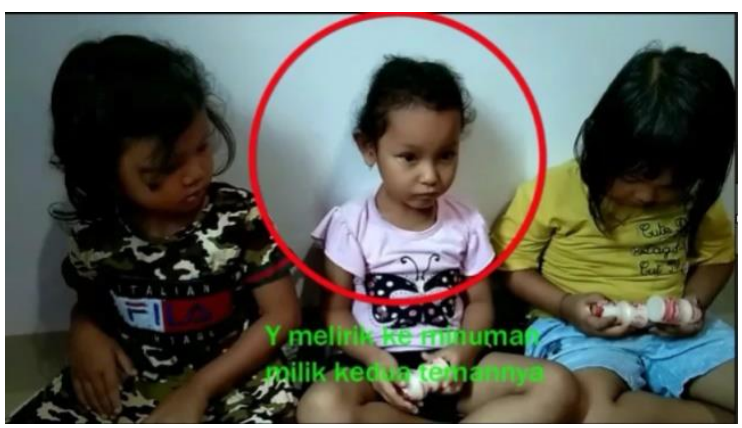

Figure 6. The expression $Y$ disappointed after a glance at her friend's drink

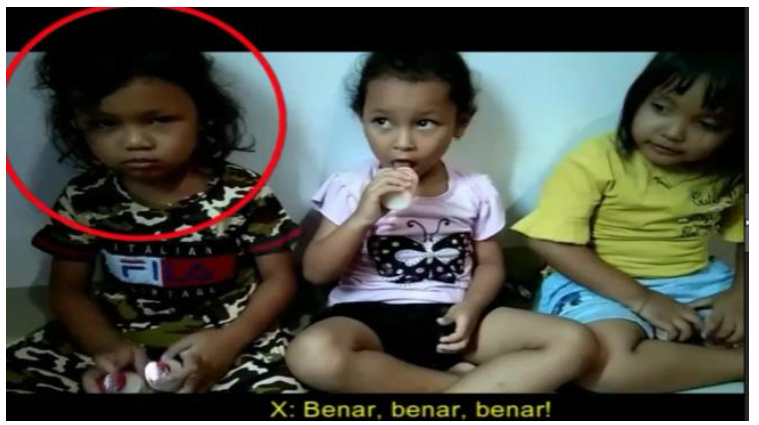

Figure 7. The expression of $X$ which looked furious because $\mathrm{Z}$ got more than $\mathrm{X}$ 


\section{Segment 3:}

In segment 3, chocolate bars are provided. $X$ gets 3 bars, Y gets 2 bars, and $\mathrm{Z}$ gets 1 bar.

After finishing the distribution, $\mathrm{Z}$ immediately looked at his friends and said, "I only got 1 , but that is a lot (pointing to X's chocolate)" with a sad voice and expression (Figure 8).

When the researcher asked whether the distribution was fair, $X$ answered that the distribution was unfair, and then when asked why it was unfair, $\mathrm{Z}$ answered because it was "not the same". After being asked a few questions, $\mathrm{Z}$ was able to reveal that to be fair, and he had to get two chocolates (Figure 9).

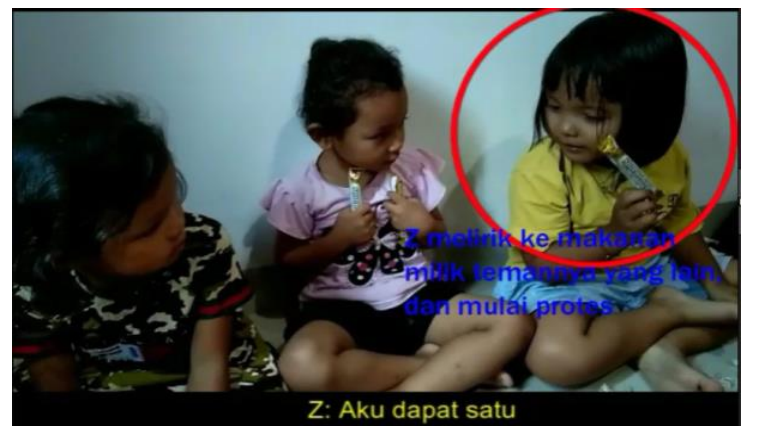

Figure 8. Z complains because she got only one chocolate

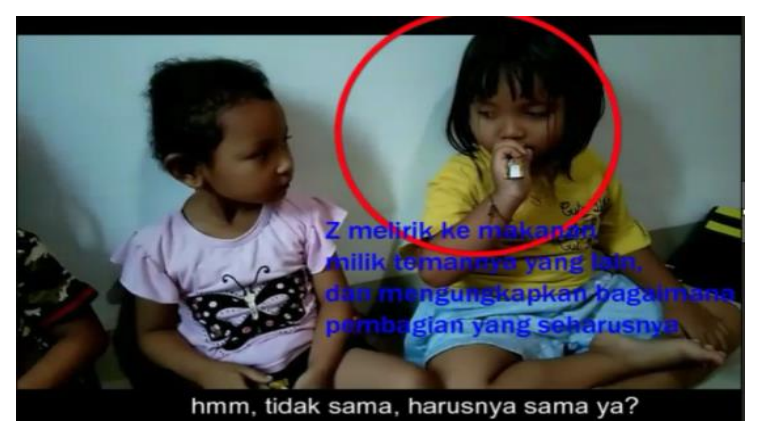

Figure 9. The expression $\mathrm{Z}$ who is upset and reveals how the correct division supposed to be done

\section{Segment 4:}

In segment 4 , the wafers are provided. $\mathrm{X}, \mathrm{Y}$, and $\mathrm{Z}$ get the same number of wafers, which are 2 .

When asked if the distribution was correct, they answered "correct". Then the researchers asked about the number of wafers they received. Each subject could answer correctly. Moreover, in this segment, each subject's facial expressions indicate that no one feels disappointed with the wafer's distribution.

\subsection{Understanding the Concept of Dividing 3-5 Years Old Children through the Idea of "Fairness"}

From the implementation of segment 1 to segment 3, the amount of food given by each subject varies, and it can be seen that each subject who gets the least share shows an expression of disappointment or disagreement with the distribution (see Figure 2; Figure 4; Figure 6; Figure 7; Figure 8; Figure 9). Children at an early age tend to give negative responses when faced with unfair distribution of certain resources [18]. In the 4th segment, each subject gets the same amount of food. Therefore no disappointed reactions or gestures occur. The expressions shown by the subjects after getting the food were satisfied, and when they were asked whether the distribution was correct, all of them answered "correct". This fact shows that children aged 3-5 years had already known the idea of fairness through fair sharing; in this case, it is equality in quantity, which in mathematics content is usually applied to division. Building on the initial understanding of division through "fairness" and "equal sharing", the idea of fairness was usually familiar to children before the division concept first encountered in a formal sense. The idea of equal sharing is also often obtained informally from everyday activities such as sharing candy, food, or toys [5].

Based on the activities that had been carried out, it could be seen that the subjects actually already had an initial understanding of the division, although not in the form of mathematical symbols. This fact is in accordance with the opinion of other researchers who revealed that the development of children's mathematics skills occurred much earlier in real-world contexts than in the classroom [1]. Although children might not develop the ability to use algorithms before learning them in class, children are able to deal with basic arithmetic, including division and fractions, in everyday life before they formally learn these concepts in school [6].

In segments 1 to 3 , the subjects who get the most parts tend to be happy, and when asked if the division is correct, the subject will immediately answer "correct". The cognitive level of the subject influences this. According to Jean Piaget's theory of cognitive development, subjects at the age of 3-5 years enter the pre-operational development stage where one of the obstacles in this stage is the egocentric nature of the child, and the child only focuses on himself, and have not been able to see from the perspective of others [19]. Even though all the subjects understand this injustice, but the subjects who got more shares did not make any corrections. It is because children tend to agree to choices that benefit themselves [9] [20].

In carrying out activities, not all subjects could express their feelings well. This condition is influenced 
by cognitive development and self-confidence based on their family background and environment. The quality of the family environment and the surrounding environment affects children's cognitive development because the home and surroundings are the main sources of stimulation for preschool children's cognitive development [21]. Children's cognitive factors, such as working memory, language fluency, play an important role in early mathematic development and can influence mathematic performance [14].

\section{CONCLUSION}

Based on the series of activities that have been carried out, it can be concluded that children aged 3-5 years already have an initial understanding of division, where this understanding is built through the idea of 'fairness' in "fair sharing". It can be observed from the responses and expressions of the subjects who reluctantly accept when they get an amount of food which is different from others. 2 out of 3 subjects have also been able to express their disagreement. Their ability to speak it up was influenced by cognitive development and self-confidence based on family background and the surrounding environment.

\section{ACKNOWLEDGMENTS}

Thank you to the three subjects $\mathrm{X}, \mathrm{Y}$ and $\mathrm{Z}$ and their parents who have been willing to be the subject and support this research. Thanks also to Dr. Darmawijoyo, M.Si. and Dr. Somakim, M.Pd, for providing input and guiding us throughout the research process and in writing this article.

\section{REFERENCES}

[1] L. Horton, Understanding the concept of division, East Tennessee State University, 2007.

[2] C. Björklund, M. van den Heuvel-Panhuizen, A. Kullberg, Research on early childhood mathematics teaching and learning, ZDM, vol. 52, 2020, pp. 607-619.DOI: https://doi.org/10.1007/s11858-020-01177-3

[3] I. Novikasari, Matematika dalam Program Pendidikan Anak Usia Dini (PAUD), Bunayya: Jurnal Pendidikan Anak, vol. 4 no.1, 2016, pp. 116 .

[4] M. Warden, Judgement and reasoning in the child. Taylor \& Francis e-Library, Great Britain, 2002.

[5] A. Harris, Multiplication \& division. University of Northampton, United Kingdom, 2001.

[6] R. S. Parmar, Understanding the concept of "Division": Assessment considerations Exceptionality, vol. 11 no. 3, 2016, pp. 177-189.
DOI:http://dx.doi.org/10.1207/S15327035EX1103 $-05$

[7] W. Zhang, S. Xiang, H. Dai, M. Ren, Y. Shen, W. Fan, Y. Zhong, The impact of self-relevance on preschool children's sharing, Frontiers in Psychology, vol. 10 no. 1028, 2019, pp. 1-13. DOI: doi: 10.3389/fpsyg.2019.01028.

[8] A. Shaw, K.R. Olson, Children discard a resource to avoid inequity, Journal of Experimental Psychology: General, vol. 141 no. 2, 2012, pp. 382-395. DOI: 10.1037/a0025907

[9] V. LoBue, T. Nishida, C. Chiong, J.S. DeLoache, J. Haidt, When getting something good is bad: Even three-year-olds react to inequality, Social Development, vol. 20 no. 1, 2011, pp. 154-170. DOI: $10.1111 / \mathrm{j} .1467-9507.2009 .00560 . \mathrm{x}$

[10] R.B. Anwar, Analisis kesulitan be;ajar matematika pada anak usia dini (Tingkat pras sekolah/TK) dan alternatif pemecahannya, GUIDENA: Jurnal Ilmu Pendidikan Psikologi Bimbingan dan Konseling, vol. 1 no. 1, 2011, pp. 63-72.

[11] D.C. Geary, Cognitive predictors of achievement growth in mathematics: A 5-years longitudinal study, Developmental Psychology, vol. 47 no.6, 2011, pp. 1539-1552. DOI: 10.1037/a0025510

[12] M.M. Hannula-Sormunen, E. Lehtinen, P. Räsänen, Children's preschool subitizing, spontaneous focusing on numerosity and counting skills as predictors of mathematical performance 6-7 years later at school, Mathematical Thinking and Learning, vol. 17, 2015, pp. 155-177. DOI: 10.1080/10986065.2015.1016814

[13] M.M. Lüken, Repeating pattern competencies in three- to five-year old kindergartners: a closer look at strategies, Contemporary Research and Perspectives on Early Childhood Mathematics Education (ICME-13 Monographs) ed I Elia, J Mulligan, A Anderson, A Baccaglini-Frank and C Benz (Cham: Springer International Publishing) chapter 3, 2018, pp. 35-53. DOI: https://doi.org/10.1007/978-3-319-73432-3_3

[14] G. Bojorque, J. Torbeyns, M. Hannula-Sormunen, D. Van Nijlen, L. Verschaffel, Ecuadorian kindergartners' spontaneous focusing on numerosity development: Contribution of numerical abilities and quality of mathematics education, Contemporary Research and Perspectives on Early Childhood Mathematics Education (ICME-13 Monographs) ed I Elia, J Mulligan, A Anderson, A Baccaglini-Frank and C Benz (Cham: Springer International Publishing) 
chapter 5, 2018, pp 69-86. DOI: https://doi.org/10.1007/978-3-319-73432-3_5

[15] P. Sullivan, R. Zevenbergen, J. Mousley, The context of mathematics tasks and I context of the classroom: Are we Including all Students?, Mathematics Education Research Journal, vol. 15 no. 2, 2003, pp. 107-121.

[16] S.J. Bram, A.D. Taylor, Fair Division From CakeCutting to Dispute Resolution. Cambrodge University Press, New York, 1996.

[17] A. Shaw, N. Montinari, M. Piovesan, K.R. Olson, F. Gino, M.I. Norton, Children develop a veil of fairness, Journal of Experimental Psychology: General, vol. 143, 2013, pp. 363. DOI: $10.1037 / \mathrm{a} 0031247$

[18] K, Lucca, J. Pospisil, J.A. Sommerville, Fairness informs social decision making in infancy, PLoS ONE, vol. 13 no. 2, 2018, pp. 1-14. DOI: https://doi. org/10.1371/journal.pone.0192848

[19] S.A. Mu'min, Teori Perkembangan Kognitif JEan Piaget, Jurnal Al Ta'dib, vol. 6 no. 1, 2013, pp. 89-99.

[20] P.R. Blake, K. McAuliffe, "I had so much it didn't seem fair": Eight-year-olds reject two forms of inequity, Cognition, vol. 120, 2011, pp. 215-224. DOI: doi:10.1016/j.cognition.2011.04.006

[21] E. Elmanora, D. Hastuti, I. Muflikhati, Lingkungan keluarga sebagai stimulasi utama untuk perkembangan kognitif anak usia prasekolah, Jurnal Ilmiah Keluarga dan Konseling, vol. 10 no.2, 2017, pp. 143-156. DOI: http://dx.doi.org/10.24156/jikk.2017.10.2.143 